\title{
Rufus Nims: Mid-century Modern and Florida Tropical Architecture
}

\author{
Emily Mason \\ College of Design, Construction and Planning, University of Florida
}

Faculty mentor: Vandana Baweja, School of Architecture

\begin{abstract}
Mid-century modern architecture developed after the Second World War as numerous technological advancements allowed for open house plans with the increased use of glass and a reconfiguration of indoor-outdoor relationships. Rufus Nims, a Miami architect (1913-2005), hybridized emerging ideas of mid-century modernism with climatic design that emerged in the field of tropical architecture after the Second World War. Nims experimented with homes that had disappearing walls; and that could be comfortable in the hot and humid climate of Florida. This paper will analyze Rufus Nims' role in the development of Florida Tropical Architecture, through his seamless integration of indoor and outdoor spaces. Further, this study will assess how Rufus Nims used tropical architecture strategies in South Florida, such as screened-in porches, disappearing walls, and landscape integration. The paper argues that Rufus Nims' architectural ideas were based on an emerging redefinition of the indoor-outdoor spatial relationships as was evident in the broader mid-century modern movement and Florida Tropical Architecture.
\end{abstract}

\section{Introduction}

\section{Mid-century Modern}

In Europe, the modernism movement began after the First World War with a need to industrialize the building production process, minimize the cost of construction, and provide a livable home designed for human habitation. ${ }^{1}$ Architects from Germany including Walter Gropius, Marcel Breuer, and Mies van der Rohe came to America during the 1930s at Harvard and changed Harvard's emphasis from Beaux-Arts Architecture to Bauhaus modernism. Other important architects from Europe came to America during this period including Richard Neutra, R.M. Schindler, Eliel Saarinen, and Albert Frey. ${ }^{2}$ Proponents of Modern architecture departed from the Arts and Crafts tradition to create architecture that was unornamented, devoid of decorative excesses, and based on the aesthetics of precision with high levels of craftsmanship. These architects inspired a new movement of design that helped Americans restore the economy after the Great Depression. The construction of new homes was halted during the Second World War as American soldiers were shipped off overseas, while the remaining Americans were joining in the war effort. ${ }^{3}$ 
After the Second World War, millions of soldiers returned, eager to settle into new homes. In 1944 alone, 114,000 new single-family homes were built to accommodate the returning soldiers. ${ }^{4}$ The technological advances that were intended for war efforts, when applied to postwar architecture, enabled buildings with more open spaces using light-weight materials and new structural methods to re-innovate the home. ${ }^{5}$ European modernism also inspired the expansion of glass in buildings to create entire glass walls, creating transparency in the buildings. Advances in material engineering that resulted from the Second World War allowed designers to open the plan of the house and create more dynamic spaces using floor-to-ceiling glass windows. Mid-century modern architecture resulted due to an amalgamation of war technologies, expansion of suburban living, and a greater integration of indoors with the outdoors.

\section{Tropical Architecture}

Tropical architecture is defined differently in the diverse fields of architecture such as colonial architecture, vernacular architecture, and mid-twentieth century modern architecture. The period, context, and discipline are key factors in determining what the term tropical architecture truly means. For this essay regarding the work of Miami-based architect Rufus Nims, tropical architecture best identified as an example of mid-century modernist architecture. While tropical modern architecture was believed to be developed in London and then dispersed throughout the colonized cities in the tropics, Vandana Baweja's paper on "Otto Koenigsberger and the Development of Tropical Architecture in India, 1939-1951" challenged this idea. ${ }^{6}$ The paper proved that tropical modern architecture originated in the tropics and the ideas of multiple architects such Leo De Syllas, George Atkinson, and Otto Koenigsberger ventured to London to form the Department of Tropical Architecture (1954-1971) at the Architectural Association School of Architecture in London. ${ }^{7}$

In the late nineteenth and early twentieth century, architects in the tropics developed tropical architecture in the discipline of hygiene to design buildings that solved tropical health problems. This was accomplished through the environmental design strategies of ventilation and proper lighting. In the 1950s, an epistemological shift in tropical architecture occurred that changed the emphasis from hygene to comfort. This resulted in the greater use of natural light, enhanced indoor-outdoor living spaces, and an increased emphasis on natural ventilation that resulted in a more comfortable living environment in a tropical climate. ${ }^{8}$ 
Miami tropical architecture. Miami's architecture, prior to the widespread use of airconditioning, used climate adaptive design in designing comfortable homes. Climate adaptive tropical architecture meant that the architect deployed natural elements and architectural features to mitigate the impact of intense sunlight, heat, and violent rainstorms on the interior of a building. Miami has a humid tropical climate that, in the absence of air-conditioning, needs higher rates of natural ventilation and breeze flow to cool the house, deep overhangs to minimize the sunlight exposure and heat intake, and screened porches to maximize the indoor-outdoor space while keeping bugs and insects away.

Since Miami receives twice the amount of rain than the national average, architects must shelter the house from these elements while also opening sections of the house to allow breeze in to cool the rooms. ${ }^{9}$ An optimal approach to maximize the amount of breeze a room receives is to organize the plan of the house so as to have single-depth rooms allowing for the breeze to enter each room in at least two different locations. By having two openings to cool the rooms, the house is also cross-ventilated. When creating a floorplan, Miami architects avoided interior hallways that would interrupt air flow, and instead opted for transitional indoor-outdoor spaces that functioned as hallways and secondary rooms. ${ }^{10}$ To protect the openings of the house while simultaneously allowing air movement, operable louvers and jalousies were added to windows, glass walls, or sliding-glass doors to prevent sunlight from heating the house. Louvers and jalousies are angeled slates that are used to control the amount of breeze and light that can penetrate through a building. Lastly, Miami architects used deep overhangs to shade the interior and shield the house from rain storms. ${ }^{11}$

\section{Rufus Nims}

Rufus Nims was a Miami-based architect born in Pensacola, Florida in 1913. Nims attended North Carolina State University in 1934, just a few years before it became the second university in America to adopt modernism. Nims later apprenticed for Thomas W. Cooper in Raleigh, North Carolina, but felt that his practice was too traditional. Nims visited Miami for the first time during World War II where he felt attracted to the warm environment to practice architecture. ${ }^{12}$

George Reed, Robert Bradford Browne, Peter Jefferson, Hernando Acosta and Milton Harry were some of the architects that worked with Rufus Nims before working on their own. ${ }^{13}$ Nims inspired these architects to utilize tropical design throughout their work, which is shown in 
Hernando Acosta's skyscrapers and Milton Harry's airport work. ${ }^{14}$ Nims believed that to properly design a building, one must first take apart the design factors such as materiality and structure, to maximize efficiency and design. ${ }^{15}$

\section{Rufus Nims Residential Design}

Rufus Nims was primarily concerned with climate-specific architecture that used lightweight construction to create a comfortable environment in the hot and humid Florida climate. Nims was largely a residential architect. Nims oriented the house optimally and used singledepth rooms to cross-ventilate the house. Since the weather is excessively hot in Florida; deep overhangs, louvers, and jalousies were essential in the design of the homes to protect them from sunlight, heat, and rain. Nims raised the homes off the ground to protect them from hurricanes and termites, while simultaneously providing occupants a view of the surroundings. By raising the houses, the rooms became more private as they were above the bystanders' sightlines at the street level and the house was more protected from bugs, since they stay closer to the landscape. ${ }^{16}$

concrete. With the development of the modernist movement in the mid-twentieth century, numerous architects experimented with the formal and structural possibilities of concrete. Rufus Nims was one of these architects to experiment with concrete, specifically looking at how concrete could be used in tropical Florida. He used the concrete to make inexpensive, simple homes that could be as functional as possible. ${ }^{17}$ The concrete allowed for a strong structure that could resist hurricanes and termites, and could be easily cantilevered to "protect the interior against too much sun, glare, or rain." ${ }^{18}$ Le Corbusier's work inspired Nims in the use of concrete construction to create an open floor plan by eliminating interior walls. Le Corbusier's Maison Dom-ino used two planes; the roof and floor, which were supported by six concrete columns. This open plan concept allowed for floor-to-ceiling windows, which brought in natural light and connected the interior to the outdoors. To make curved walls, Nims pioneered the use of laminated concrete that was sprayed in layers using less material in the process. An example of this laminated concrete construction is the Straus Residence that will be covered in detail later in the paper.

During the 1950s, concrete became more expensive, which discouraged architects from using it abundantely in homes. ${ }^{19}$ Rufus Nims responded to the higher cost of concrete by using 
screened cages, otherwise known as screened porches, to limit the solid concrete walls. The screened porch was less expensive than concrete, allowing for natural breeze to cool the interior space while protecting it from bugs. The screened porch also created better indoor-outdoor relationships as it allowed for a transition space within the residence. The screened spaces with deep overhangs for shade allowed people to experience Florida's weather while keeping out the bugs and sun.

\section{Roman Residence, Miami, 1948, in association with William Jameson}

Nims first house that utilized concrete construction was the Charles Roman House in Miami, Florida. ${ }^{20}$ The Roman Residence mimicked the idea of Le Corbusier's Maison Dom-ino by having the entire house float above the ground, allowing for each room to flow into each other, including the landscape (Figure 1). By elevating the house, Nims provided rooms that were not at eye-level for people who passed by, thus adding much needed privacy for the residents in a house that was very open. The elevated house could also capture more natural breeze that cooled the house, thus ventilating the rooms as the house was raised off the ground. By having the house elevated on stilts, the rooms were protected from hurricanes, flooding, and severe storms. To further protect the Roman Residence from tropical storms, Nims developed wooden jalousies that were strong enough to resist wind or rain when closed completely. ${ }^{21}$

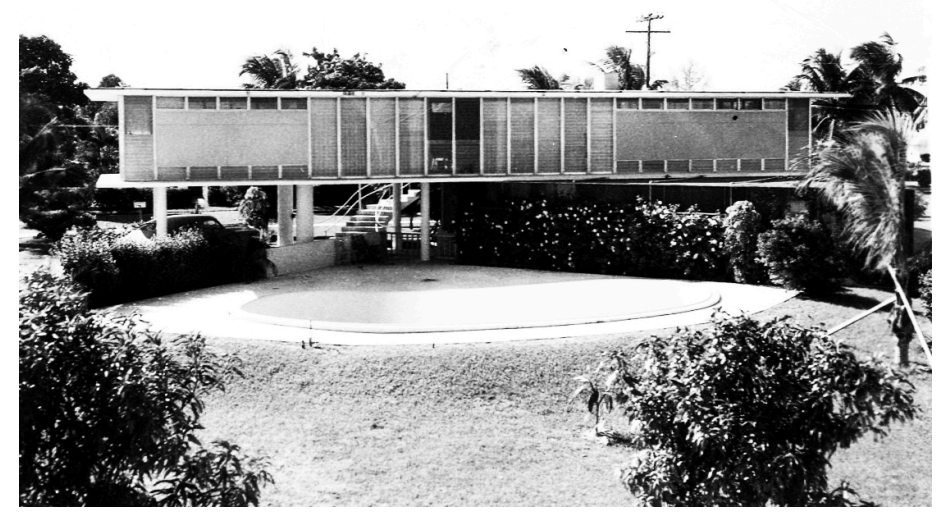

Figure 1: Photograph of Roman Residence, Miami, Florida, 1948, architect: Rufus Nims and William Jameson. Source: Roman Residence, Rufus Nims Architectural Drawings, Special and Area Studies Collections, George A. Smather's Libraries, University of Florida, Gainesville, Florida

\section{Adler Residence, Miami Beach, 1952, in association with William Jameson}

For Nims, the adaptation of Le Corbusier's Maison Dom-ino concept after the Roman Residence was refined in the design of the Adler Residence. The Adler Residence structure 
consists of eight concrete columns which support the roof and the floor concrete slabs, such that the slabs appear to float in space. ${ }^{22}$ By having a column-based structure, Nims was able to have a completely open interior space (Figure 2). The internal elements of the Adler Residence, such as the built-in shelving units, compacted kitchen, and furniture, were suspended from the floor allowing for better air circulation and clean space throughout the interior. ${ }^{23}$ Nims also suspended the solid walls within strips of glass to show that the walls are not the structural elements, but the column based structure is. ${ }^{24}$ Instead of having the pool adjacent to the ground, Nims raised the pool to an intermediate level allowing for the indoor-outdoor relationship to be strengthened. ${ }^{25}$ Connecting the main entrance, pool deck, and main living level was a cascading stair case.

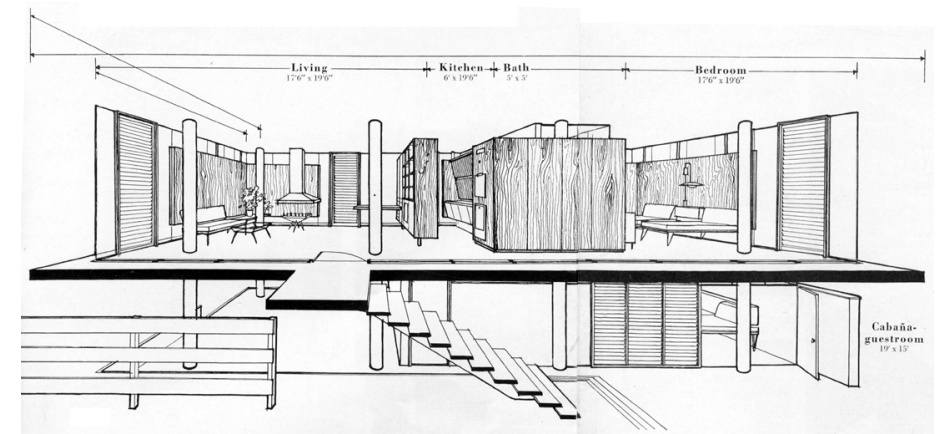

Figure 2 Diagrammatic Drawing of the Adler Residence, Miami Beach, 1952. Source: "Headline House \#1: Adler House." House and Garden, July 1952

\section{Stillman Residence, Coconut Grove, Miami, 1953}

Nims employed 'zones' to his homes to separate the main rooms for greater functionality. The Stillman Residence in Coconut Grove clearly shows the concept of the zoned house as it zones the living area and bedrooms apart from each other, while also separating the adults from the children to give each occupant their personal space ${ }^{26}$ (Figure 3). There are two separate wings to the house; the main living area and the bedrooms. Between these zones, a garden space is located with a screened porch to bring in the outdoor experience while keeping away the bugs.

In addition, the area surrounding the house is full of foliage to naturally block the strong sunlight, solar heat intake, and to protect the house from storms. ${ }^{27}$ The house is made up of single-depth rooms, with each room having access to the central garden. With single-depth rooms, Nims could better cross-ventilate the rooms as the breeze can reach each room through the central garden. Nims also extended the overhangs throughout the exterior of the house to prevent the sun from heating the rooms. Since the interior space is relatively small, Nims used 
built-in furniture such as custom designed cabinets, and redesigned a refrigerator, to minimize the amount of space used and increase the functionality of the household. ${ }^{28}$

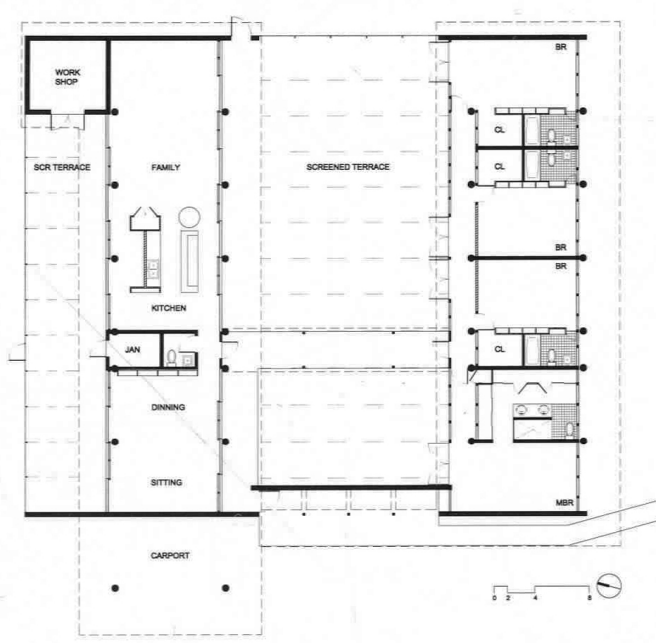

Figure 3: Plan of the Stillman Residence.

Source: Jan Hochstim, "Rufus Nims" in Florida Modern: Residential Architecture 1945-1970, Ed. Jan Hochstim (New York: Rizzoli, 2004), 82-95

\section{Messmore Residence, St. Petersburg, 1956}

In the Messmore Residence, Nims created two elongated gardens with the house in between (Figure 4). The gardens on the front and the back of the house were enclosed with a louvered wall in the front and a screened-in porch in the back to create privacy while maintaining the waterfront view. ${ }^{29}$ If the sliding-glass walls were completely opened throughout the house, it would become a screened-in room entirely, thereby representing a true indoor-outdoor house. ${ }^{30}$ The house contains single-depth rooms allowing for each room to experience the gardens and maximize the amount of breeze intake for maximum cross-ventilation. Nims planned the house so that the living area was in the center, dividing the children's rooms area from the parent's bedrooms zone. ${ }^{31}$ Each room was accessed by an outside loggia within the gardens. ${ }^{32}$ The loggia allowed for the residences to be covered under a roof that separated the house from the outdoors. This separation could be considered an outdoor hallway with the comfort of the home. Instead of the Maison Dom-ino structure, Nims deployed slender steel columns and masonry partitions to 
divide the interior space. ${ }^{33}$ He also used redwood throughout the house including the louver panels, walls, and built-in furniture to create a cool and comfortable atmosphere. ${ }^{34}$

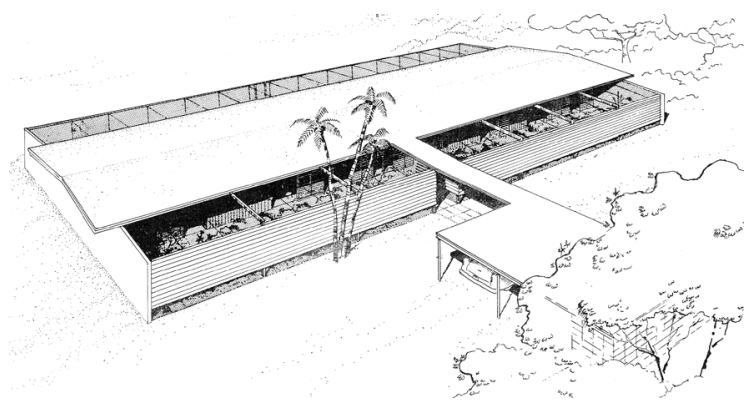

Figure 4: View of Messmore Residence.

Source: Messmore Residence, Rufus Nims Architectural Drawings, Special and Area Studies Collections, George A. Smather's Libraries, University of Florida, Gainesville, Florida

\section{Straus Residence, Key Biscayne, 1968}

Rufus Nims experimented with 'shotcrete' construction by applying concrete or stucco through a spray gun. This made construction more economical as the cost of laminated concrete was almost a half that of a concrete block. ${ }^{35}$ In addition, with the use of shotcrete the building sections could be thinner, which gave Nims a lot of freedom in creating free-forms as the geometry of the structure did not have to be rectilinear. Nims developed a modified "igloo" structure using shotcrete construction which he transformed to a human scale. The Straus Residence incorporated the igloo structure to make each room in an igloo form with a total of eleven igloo rooms, which were separated in a circular plan formation that allowed better ventilation and more outdoor living (Figure 5).

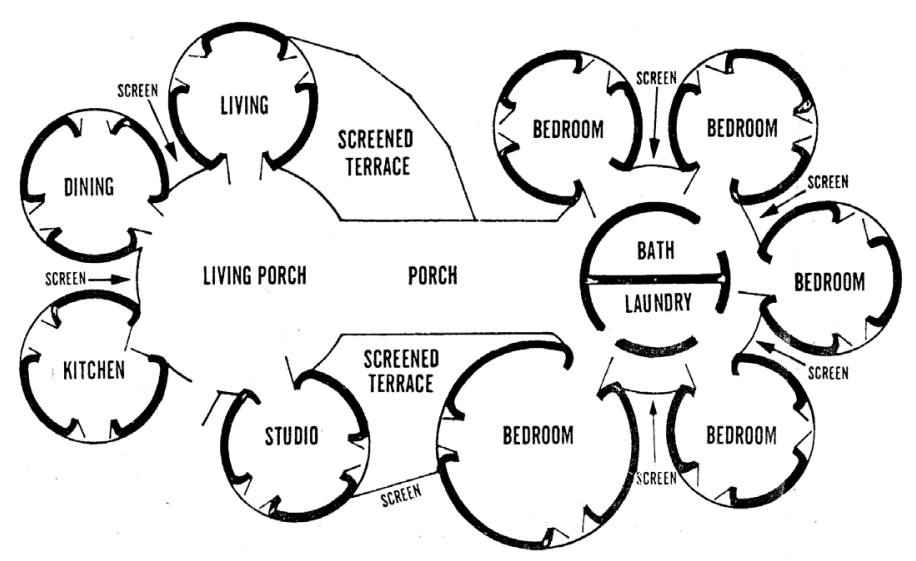

Figure 5: Plan of Straus House.

Source: "Sprayed-On Concrete, Wood Offer Cost-Cutting Ideas." Miami Herald, June 10, 1973 


\section{Conclusion}

Rufus Nims merged ideas of openness developed through mid-century modern architecture with tropical architecture to create a comfortable yet open floor plan in a hot and humid environment. The techniques Nims used such as floor-to-ceiling glass walls, louvers, jalousies, and deep overhangs were some examples of how a home could be passively designed. This Miami architect, although not as well-known as other Florida architects like Paul Rudolph or Alfred Browning Parker, deserves to be recognized for his influential work in the creation of climate-specific modern architecture after the Second World War.

\section{Endnotes}

${ }^{1}$ Michael Webb, Modernism Reborn: Mid-century American houses (New York: Universe, 2001), 813.

${ }^{2}$ Deborah K. Dietsch, Classic Modern: Mid-centuryMid-century Modern at Home (New York: Simon \& Schuster, 2001), 12-23.

${ }^{3}$ Webb, Modernism Reborn: Mid-century American houses, 8-13.

${ }^{4}$ Dietsch, Classic Modern: Mid-centuryMid-century Modern at Home,12-23.

${ }^{5}$ Ibid.

${ }^{6}$ Vandana Baweja, "Otto Koenigsberger and the Development of Tropical Architecture in India, 1939-1951," Arris: Journal of the Southeast Chapter of The Society of Architectural Historians 25 (2014): 2-17.

${ }^{7}$ Ibid.

${ }^{8}$ Ibid.

9 "A New Architecture for Tropical Florida: How to Be Comfortable (Summer and Winter) Despite Heat, Glare, Rains, Rot, Hurricanes, and Bugs," Architectural Forum 94 (February 1951):131-139.

${ }^{10}$ Ibid.

${ }^{11}$ Ibid.

${ }^{12}$ Reviews 1985: Tropical Tribute: An exhibition honors Rufus Nims, master of tropical architecture, Rufus Nims Architectural Drawings, Special and Area Studies Collections, George A. Smather's Libraries, University of Florida, Gainesville, Florida.

${ }^{13}$ Ibid.

${ }^{14}$ Ibid.

15 "Rufus Nims: Three Generations of Tropical Architecture." Milton C. Harry to Exhibition at the Metropolitan Museum and Art Center. November 6, 1986. Metropolitan Museum and Art Center, New York, New York.

${ }^{16}$ Allan T. Shulman, "Rufus Nims and the Fascination of the Concrete Home," in Miami Modern Metropolis: Paradise and Paradox in Mid-centuryMid-century Architecture and Planning, Ed. Allan T. Shulman (Miami Beach: The Bass Museum of Art, 2009), 368-375.

${ }^{17}$ Ibid.

18 "House on Stilts," House and Home 5 (March 1954): 134-39. 
${ }^{19}$ Shulman, "Rufus Nims and the Fascination of the Concrete Home," 368-375.

${ }^{20}$ Ibid.

${ }^{21}$ Peg Leithiser, "Nims Designs Residence to Meet Climatic Needs," Miami Sunday News, (April 1950).

22 "Headline House \#1: Adler House," House and Garden (July 1952): 32.

23 "House on Stilts," House and Home,134-39.

${ }^{24}$ Ibid.

${ }^{25}$ Shulman, "Rufus Nims and the Fascination of the Concrete Home," 368-375.

${ }^{26}$ Ibid.

${ }^{27}$ Jan Hochstim, "Rufus Nims" in Florida Modern: Residential Architecture 1945-1970, Ed. Jan Hochstim (New York: Rizzoli, 2004), 82-95.

${ }^{28}$ Ibid.

${ }^{29}$ Ibid.

30 "The Screened-In Florida Room." Architectural Record 121 (May 1957): 120-23.

${ }^{31}$ Ibid.

32 "Living Here is Like Living in the Shade of a Tree." Miami Herald, April 8, 1956.

${ }^{33}$ Hochstim, "Rufus Nims" in Florida Modern: Residential Architecture 1945-1970, 82-95.

${ }^{34}$ Ibid.

35 “Sprayed-On Concrete, Wood Offer Cost-Cutting Ideas," The Miami Herald, June 1973. 